\title{
Hagfish predatory behaviour and slime defence mechanism
}

SUBJECT AREAS: ANIMAL BEHAVIOUR

ECOLOGY

ZOOLOGY

THEORY

Received

24 August 2011

Accepted

12 October 2011

Published

27 October 2011

Correspondence and requests for materials should be addressed to V.Z. (vincentz@ tepapa.govt.nz)

\author{
Vincent Zintzen', Clive D. Roberts', Marti J. Anderson ${ }^{2}$, Andrew L. Stewart' ${ }^{1}$, Carl D. Struthers' \\ \& Euan S. Harvey ${ }^{3}$ \\ ${ }^{1}$ Museum of New Zealand Te Papa Tongarewa, 169 Tory Street, Wellington, New Zealand, ${ }^{2} \mathrm{New}$ Zealand Institute for Advanced \\ Study, Massey University, Albany Campus, Private Bag 102 904, Auckland, New Zealand, ${ }^{3}$ School of Plant Biology and UWA \\ Oceans Institute, The University of Western Australia (M470), 35 Stirling Highway, Crawley WA 6009, Australia.
}

Hagfishes (Myxinidae), a family of jawless marine pre-vertebrates, hold a unique evolutionary position, sharing a joint ancestor with the entire vertebrate lineage. They are thought to fulfil primarily the ecological niche of scavengers in the deep ocean. However, we present new footage from baited video cameras that captured images of hagfishes actively preying on other fish. Video images also revealed that hagfishes are able to choke their would-be predators with gill-clogging slime. This is the first time that predatory behaviour has been witnessed in this family, and also demonstrates the instantaneous effectiveness of hagfish slime to deter fish predators. These observations suggest that the functional adaptations and ecological role of hagfishes, past and present, might be far more diverse than previously assumed. We propose that the enduring success of this oldest extant family of fishes over 300 million years could largely be due to their unique combination of functional traits.

agfishes have been the subject of much evolutionary research due to their unique body plan which places them potentially at the origin of vertebrates ${ }^{1-4}$. Hagfishes are also considered as being important components in the ecology of many ecosystems due to their high relative abundance, burrowing behaviour and feeding activities which generate turnover of substrates and recycling of organic matter ${ }^{5,6}$. In addition, they can represent significant prey items for marine mammals, sharks and cephalopods ${ }^{5}$. However, despite their widespread abundance in the deep sea, much of the basic biology of hagfishes, including feeding behaviour, remains a mystery. Hagfishes are commonly considered to feed exclusively by opportunistic scavenging, having been observed primarily feeding on carrion falls $s^{7,8}$ or discards from fisheries ${ }^{9,10}$, and having also been caught in large numbers in baited traps ${ }^{10-13}$. Hagfishes may also exploit prey captured by other organisms, such as sea stars and $\mathrm{crabs}^{14}$. It has been postulated, however, that the high densities of hagfishes in the deep sea are unlikely to be sustained by scavenging alone ${ }^{15}$. This view is further supported by analyses of stomach contents from hagfishes $\mathrm{s}^{5,16}$ which included benthic invertebrates, such as prawns and polychaete worms, as well as vertebrate flesh. However, active predation by hagfishes has never previously been observed.

Hagfishes have a large battery of slime glands and 90 to 200 associated slime pores running laterally along the full length of each side of their body ${ }^{17}$ (Fig. 1a). Large volumes of slime are excreted from these pores when a hagfish is provoked or stressed ${ }^{5,12,18}$. Hagfish slime is unique, containing mucins bonded together with protein threads, which expand in contact with seawater to become almost three orders of magnitude more dilute than typical mucous secretions ${ }^{18-21}$. It is hypothesised that this copious slime has evolved as a defence against gillbreathing predators ${ }^{18-22}$. The potential effectiveness of this strategy is demonstrated by the fact that hagfishes are known to die if left in their own slime ${ }^{5}$. There have been no direct observations of the actual use of this slime by hagfishes, however, either in the wild or in aquaria.

Using footage obtained from multiple Baited Remote Underwater Stereo-Video $\left(\right.$ BRUV $\left.^{23}\right)$ deployments in the field, we show in this study that hagfishes actively secrete slime as a defence mechanism against predation by other fishes. We also describe hunting and predatory behaviour exhibited by hagfish on another live fish, as recorded and directly observed in one of our stereo-video deployments.

\section{Results}

Slime defence from predation. Video footage clearly demonstrated that slime secreted by hagfishes fills the mouth and gill chamber of their predators, acting as a very rapid $(<0.4 \mathrm{sec})$ and effective defence mechanism (see Supplementary Video S1). More particularly, at the moment that a predator grasped the body of a hagfish, jets of 

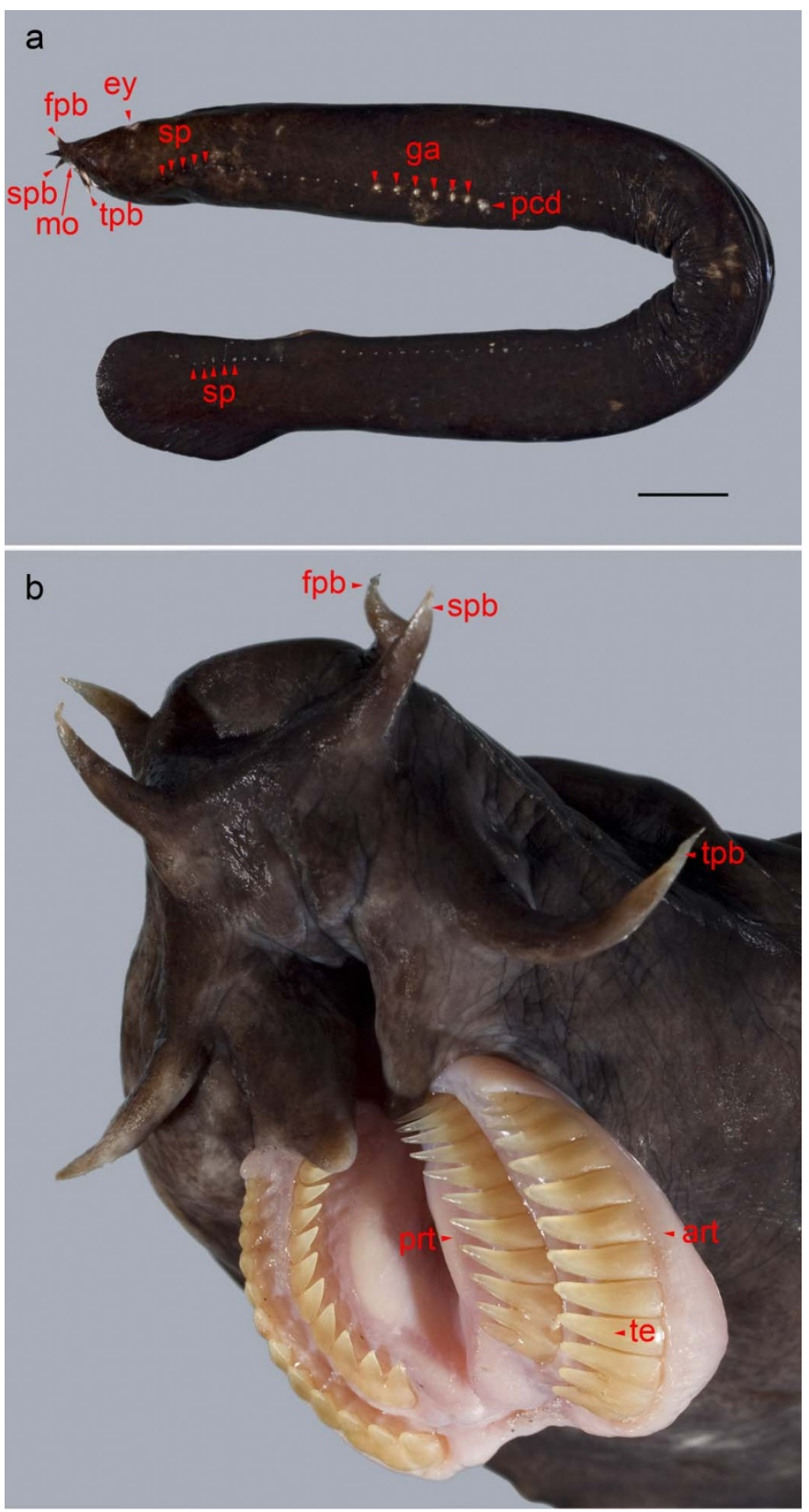

Figure 1 Hagfish toothplates and slime pores. (a) Eptatretus cirrhatus (726 mm TL, ca. 85 total slime pores), arrows show its first five (of 15) prebranchial and last five (of 13) caudal slime pores. ey, eye; fpb, first pair of barbels; spb, second pair of barbels; tpb, third pair of barbels; mo, mouth; sp, slime pores; ga, gill aperture; pcd, pharyngocutaneous duct; te, teeth; prt, posterior row of teeth; art, anterior row of teeth. Scale bar, $4 \mathrm{~cm}$. (b) Protracted and everted dental plate, exposing keratinous teeth,

which can grasp prey with biting forces that exceed some gnathostomes of similar size $e^{27}$.

slime were discharged locally only by those groups of slime glands in the mouth of the predator, causing it to visibly choke and move away from its potential prey (Fig. 2). The predators convulsed their gill arches dramatically in a gagging-type effort to clear the slime from their gill chambers. A wide diversity of fish predators fell victim to this phenomenon, including sharks and bony fishes (Table 1, Fig. 2). Out of 165 video deployments covering over 495 hours, there were 67 deployments in which hagfishes occurred, at depths ranging from 97 to $1162 \mathrm{~m}$. In 12 of these, we observed 14 separate incidents where predators were clearly repelled by hagfish slime (Table 1). The hagfishes, in all cases, appeared to sustain no injury, often continuing to feed on the bait, while the predator moved away, gagging. In addition, in other videos, when multiple hagfish were present at the bait, the bait bag would become draped in slime, deterring other fishes from approaching the food source (see also Supplementary Video S1).

Predation. In addition to the observations of the hagfish defence mechanism, we documented predatory behaviour by a slender hagfish (Neomyxine sp.1) on a red bandfish Cepola haastii (Hector) (family Cepolidae) from a stereo-video unit deployed in December 2009 at a depth of $97 \mathrm{~m}$ off Great Barrier Island, New Zealand $\left(35^{\circ}\right.$ $58.860^{\prime} \mathrm{S}, 175^{\circ} 24.103^{\prime} \mathrm{E}$, see Methods). The sequence of events identified as direct predation took a total of 2.3 minutes and is depicted diagrammatically in Fig. 3, based on the full video sequence (see Supplementary Video S2).

In this video deployment on muddy sand substratum, the level of activity of the slender hagfish was much greater than what had been observed at other sites. None of the four observed hagfish displayed any scavenging behaviour towards the nearby bait. Instead, they actively searched a small area where burrows were apparent in the sediment. After 66 minutes, a red bandfish, about $15 \mathrm{~cm}$ in total length, protruded its head outside a burrow, and ventured briefly into the water column.

During the searching phase of the hunt, hagfish displayed rapid body movements, their barbels (Fig. 1) in constant contact with the substratum. Highly localised exploration of the sediment took place in and around the burrows. On several occasions, this local search was followed by an individual assuming an angle of $90^{\circ}$ to the sea floor and swimming vigorously into a burrow until its entire body was buried in the substratum. This burrow invasion was rapid, taking less than 10 seconds. Hagfish stayed buried in the sediment for several minutes, and usually emerged from the entrance of another burrow.

After 118 minutes, one slender hagfish, measuring about $300 \mathrm{~mm}$ TL, started a local search pattern and entered a burrow up to a third of its body length. For the first minute, S-shaped spasms of muscular activity were observed on the posterior part of its body. This was followed by approximately one minute of relaxation, the posterior part of the body lying on the bottom with very little movement. The hagfish then resumed a perpendicular angle to the substratum and created an overhand knot with its posterior section, pushing its body further into the sediment in a single fast pulse until the knot contacted the sediment. Knotting and pushing took less than two seconds.

After a further twenty seconds the slender hagfish withdrew from the burrow, unknotted itself, and had the posterior part of a red bandfish held firmly in its mouth. At this time, the red bandfish did not show any sign of movement, indicating that it was either dead or incapacitated, possibly by having been suffocated in its burrow by slime exuded from the hagfish. Maintaining a firm grip on its prey, the slender hagfish then swam outside the field of view of the video unit. Although this was the only individual hagfish observed catching live prey, the other individuals all exhibited the same hunting behaviour.

\section{Discussion}

Our video deployments confirmed the hypothesis that hagfish use slime secretion as an effective defence mechanism against predation. The footage we obtained showed that slime can affect gill-breathing predators by clogging gills, likely by increasing the resistance to water flow $^{18,19,21}$. The mechanism was effective on a broad spectrum of species and feeding types. Biters (sharks, conger eels) and suckers (wreckfishes, scorpionfishes) could not successfully acquire their potential hagfish prey. From our video observations, it seems obvious that the deterrent effect was due to a gill-clogging mechanism. However, it cannot be totally ruled out that the slime could also 

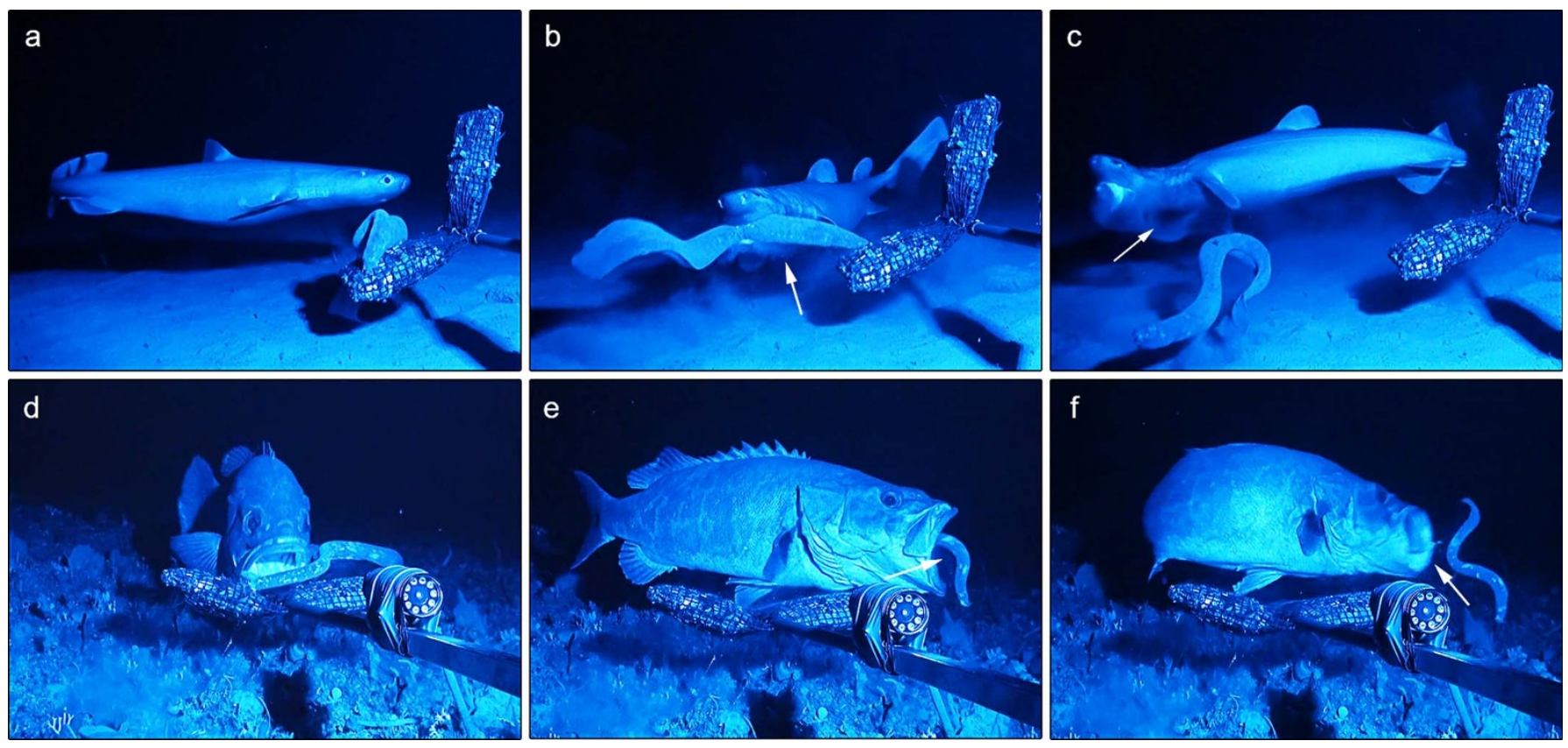

Figure $2 \mid$ Hagfish slime as a defence mechanism against gill-breathing predators. The seal shark Dalatias licha (a-c) and the wreckfish Polyprion americanus $(\mathbf{d}-\mathbf{f})$ attempt to prey on the hagfishes Eptatretus cirrhatus $(\mathbf{a}-\mathbf{c})$ and Eptatretus sp.2 (d-f), respectively. (a),(d), First, the predators approach their potential prey. (b),(e), Predators bite or try to swallow the hagfishes, but hagfishes have already projected jets of slime (arrows) into the predators' mouth. The slime secretion took less than $0.4 \mathrm{sec}$. (c),(f), Choking, the predators release the hagfishes and gag in an attempt to remove slime from their mouth and gill chamber. See Supplementary Video S1 for the full sequence of these events in action, along with other examples (Table 1).

contain toxic compounds that would trigger a predator escape response. The composition of hagfish slime has been recently analysed ${ }^{24}$ and no sign of toxic compounds has been detected. The composition of the slime is mostly seawater, with some threads of mucus along with some osmolytes, and amino acids or monoamines, all of which are chemically benign.

Of the observed biters, the seal shark Dalatias licha is well known as a voracious fish predator. Trawled specimens have been recorded as shredding other species in the cod-end ${ }^{25}$. Even small specimens introduced live into confined spaces with other fishes illicit a panic response where the other fish have jumped out of the holding tank (A. Stewart, pers. obs.). The specimen observed on the BRUV was estimated at nearly full size and yet was repelled at the moment of biting, leaving the hagfish unmarked.

The ultimate fate of these would-be predators was not observed. Hagfish slime covering the gills may lead to suffocation, or it may simply dissolve away, as hagfish slime is often considered to bind only loosely with water ${ }^{18}$. What triggers the slime secretion is likely to be direct skin stimulation by a predator. Active slime secretion was not observed when the potential predator approached the hagfish, but only began when the predator either tried to bite or engulf the hagfish. The mechanism of localised control and coordination of slime glands, as observed in our video footage, has been documented in laboratory studies ${ }^{19}$ and was highly effective to allow a full escape. It was also fast enough to prevent any injury to the hagfishes. Aquarium and lab trials ${ }^{19,21}$ have shown that jets of hagfish slime can be ejected at a speed of up to $1.8 \mathrm{~m} . \mathrm{s}^{-1}$ to a distance of $10-17 \mathrm{~cm}^{18}$. A potential advantage of the localized secretion rather than a discharge from all slime glands would be to keep a defensive response available in the event of a new aggression. It is known that by manually stimulating a captive hagfish, the production of slime can be exhausted. It is then likely that the slime glands need a period of rest to become fully operational again. Although hagfishes have been found in the analyses of stomach contents from non-piscian predators, like marine mammals and octopuses ${ }^{5}$, they do not form an important component of fish diets ${ }^{5}$. Our observations explain why hagfish appear to have very few fish predators.

In addition, not only was predation avoided, but any potential competitor for the available food was also effectively repelled indirectly by the presence of copious amounts of slime in the water produced by hagfishes, particularly when there were large numbers of hagfishes aggregating around the food source. This will likely

Table 1 | List of predatory fish species, recorded and observed in video footage, whose gills were clogged by hagfish slime.

Predator families

Scyliorhinidae - Catsharks

Squalidae - Spiny dogfishes

Dalatiidae - Seal sharks

Congridae - Conger eels

Ophidiidae - Cuskeels

Scorpaenidae - Scorpionfishes

Polyprionidae - Wreckfishes

Centrolophidae - Raftfishes
Predator species

Cephaloscyllium isabellum (Bonnaterre, 1788)

Squalus griffini Phillipps, 1931

Cirrhigaleus australis White, Last \& Stevens, 2007

Dalatias licha (Bonnaterre, 1788)

Bassanago bulbiceps Whitley, 1948

Genypterus blacodes (Forster in Bloch \& Schneider, 1801)

Helicolenus sp.

Polyprion americanus (Bloch \& Schneider, 1801)

Hyperoglyphe antarctica (Carmichael, 1819)
Hagfishes

(1)

(1) (2)

(2)

(2)

In each case, the hagfish species under attack are denoted with numbers in brackets as follows: (1) Eptatretus cirrhatus (Forster in Bloch \& Schneider, 1801 ), (2) Eptatretus sp. 2 and (3) Neomyxine sp. 1. 


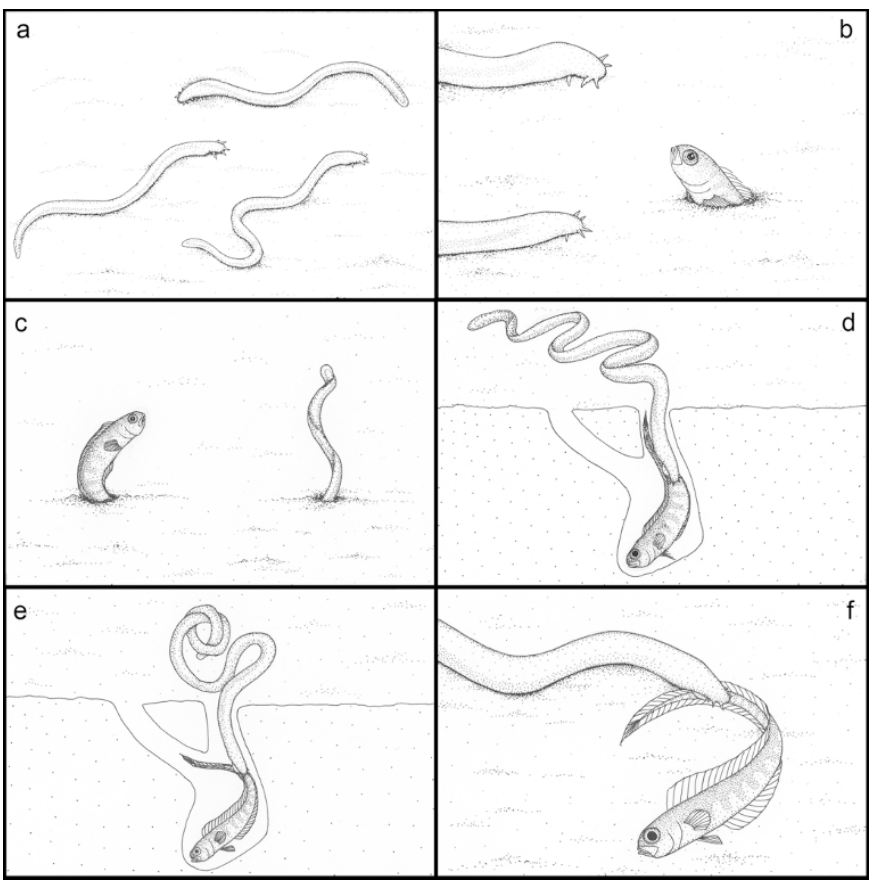

Figure 3 Sequence of events in hagfish predation. The slender hagfish Neomyxine sp.1 preys on the red bandfish Cepola haastii (see Supplementary Video S2 for the full sequence). The family Cepolidae, represented in the New Zealand region by a single endemic species, is known to have a burrowing behaviour, excavating a hole in a sedimentary bottom and emerging to feed on zooplankton ${ }^{44}$. (a) Several individuals of Neomyxine sp.1 actively search a small area of sediment where a number of C. haastii burrows were observed. (b) Cepola haastii protrudes its head outside of the burrow. (c) Neomyxine sp.1 forces C. haastii out into the water column by invading its burrow. (d) Neomyxine sp.1 enters a burrow and makes contact with the prey. The subsequent intense activity of the posterior portion of the hagfish suggests that it starts to grasp the prey by repeatedly protracting and retracting its pair of bilaterally symmetric dental plates ${ }^{27}$ (see Fig. 1b). It then goes through a period of relative inactivity where it is hypothesized that it waits for the prey to die or become incapacitated before extracting it from the burrow. It is possible that during this time lag, the hagfish suffocates its prey by producing slime. (e) Neomyxine sp. 1 with its anterior section buried in the sediment creates an overhand knot with its posterior section before extracting the prey. ( $f$ ) Neomyxine sp. 1 withdraws from the burrow with the posterior part of a C. haastii held by its toothplates, then swims away with its prey.

confer a considerable competitive advantage to hagfish in the case of small volumes of dead prey or carrion, where slime from even a single individual hagfish might limit any access by other potential scavengers. Our observations in this regard are at present of a preliminary nature, however, and additional work on the video sequences would be necessary in order to confirm and quantify the more general observation made here that hagfishes may be able to decrease competition for food by secreting slime.

Apart from scavenging, another important observation was the capacity of Neomyxine sp.1 to actively search and hunt for live prey. Hunting behaviour, although previously suspected ${ }^{5,26}$, had never been observed for any hagfish species. The discovery that this species is capable of acquiring food by means other than scavenging dead or moribund animals suggests that it could be a significant predator within its habitat. It is notable that this behaviour was observed even though bait was present less than a metre away; hagfish individuals that were actively hunting showed no interest whatsoever in the bait, which was readily accessible.

The sequence of events associated with the hunting and capture of prey by hagfish, as observed here, can be summarised in four steps:
(1) the hagfish first locates burrows potentially occupied by live prey using barbels in close contact with the sediment, and probably also using its olfactory organ; (2) once a potentially occupied burrow is located, Neomyxine sp.1 enters and makes contact with the prey. Because of the subsequent intense activity of the visible posterior part of its body, it is speculated that the hagfish then grasps and begins to swallow the prey by repeatedly protracting and retracting its pair of bilaterally symmetric dental plates $^{27}$; (3) the hagfish goes through a period of relative inactivity where it is hypothesized that it waits for the prey to die or become incapacitated before extracting it from the burrow. During this time, the hagfish may suffocate its prey by producing slime, in the same way that it does to deter predators; (4) knotting occurs to extract the prey from its burrow. The knot provides leverage for prey extraction by increasing the surface area of contact between the hagfish body and the sediment. It has also been suggested that knotting can amplify dental retractile forces to achieve a stronger grasp on the prey ${ }^{5,12}$. Knotting has also been observed as a mechanism for removing slime from the hagfish's own body surface to avoid self-entanglement ${ }^{12}$.

We propose that slime production in hagfishes has multiple functions: it deters predation by gill-breathing taxa, decreases competition for food by excluding other scavengers, and may also be a predation tool that incapacitates prey by suffocating them. It may also give innate immunity against infectious pathogens ${ }^{28}$ like the epidermal slime of the more evolved fishes ${ }^{29,30}$. Soapfish ${ }^{31}$ and boxfish $^{32}$ slime evolved into a toxic form presumably to deter predators. However, the rapid slime deployment by hagfish and its defensive action are not found in more evolved fishes and may be unique to hagfishes. There are examples of secretions used as defensive mechanisms in other groups, some being induced while others are permanent. Groups of bacteria can produce an exopolymeric matrix enabling the formation of predation-protected microcolonies large enough to deter grazing by flagellates ${ }^{33}$. Many invertebrates (e.g. sponges, cnidarians, molluscs and ascidians) use secondary metabolites often embedded in mucus for passive protection against predators, fouling, overgrowth, and ultraviolet radiation ${ }^{34}$. Some terrestrial arthropods use the discharge of a sticky secretion to immobilize the appendages of an aggressor ${ }^{35}$. Marine molluscs such as sea hares, cuttlefishes, squids, and octopuses actively release ink as a mechanism against predation, which facilitates escape by a combination of visual and chemical effects ${ }^{36}$. The use of cuvierian tubules of some species of holothuroid is another example of an active defence mechanism that is achieved by the release of a biological substance. These tubules, when irritated, are expelled as threads through the anus and become sticky in seawater, rapidly immobilizing aggressors ${ }^{37}$. In comparison to these examples, the remarkable feature of the hagfish slime defence mechanism is that it does not disrupt the foraging activity of the animal, which can continue even after an attack. This contrasts with the commonly observed response of many taxa to a heightened risk of predation through an increase in vigilant behaviour, usually at the cost of other activities ${ }^{38,39}$. For example, in many birds and mammals, this may simply mean having its head up to watch or listen for potential dangers. Hagfishes showed no sign of decreased activity when predators were present, essentially ignoring them and focussing on feeding.

The persistence of the family Myxinidae for at least the past 300 million years ${ }^{40,41}$ may be attributed to their unique combination of functional traits. They not only are able to evade predators and deter competitors through the secretion of slime, but also can adapt their feeding behaviour, which we now know includes active hunting and predation on other fishes based on these new observations. It is not clear how many of the 77 known extant species of hagfishes ${ }^{42}$ utilise predatory behaviour, nor what proportion of their diet comes from live versus dead food resources. Nevertheless, predation now seems probable across the family Myxinidae. The bite force of hagfish, through the use of both clavatus and deep protractor muscles, 
equals or exceeds that of several gnathostome vertebrates (including wrasses, turtles and finches) ${ }^{27}$. The wide gape and muscle force associated with hagfish dental plates (Fig. 1b) indicate that more advanced and faster-acting vertebrate jaws are not a unique requirement for successful predatory action. We postulate that hagfishes are the oldest extant chordate predators, that they remain active and successful hunters in the deep sea to this day, but have also evolved opportunistic feeding and scavenging strategies in response to the evolution and radiation of more highly developed jawed fishes and other vertebrates.

\section{Methods}

Baited remote underwater stereo-video (stereo BRUV) units were deployed between March 2009 and April 2010 at three locations along New Zealand's northern coast: White Island $\left(37^{\circ} 32.000^{\prime} \mathrm{S}, 177^{\circ} 11.000^{\prime} \mathrm{E}\right)$, Great Barrier Island $\left(36^{\circ} 37.000^{\prime} \mathrm{S}, 175^{\circ}\right.$ $\left.57.000^{\prime} \mathrm{E}\right)$ and the Three Kings Islands ( $\left.34^{\circ} 11.000^{\prime} \mathrm{S}, 172^{\circ} 02.000^{\prime} \mathrm{E}\right)$. At each location, videos were deployed during daylight hours at a series of depths from 50 to $\sim 1,200 \mathrm{~m}$, yielding a total of 165 deployments. The stereo BRUV units used two full High Definition Sony handycams (models HDR-CX7 and HDR-CX500) in underwater housings mounted on a base bar inside a frame ${ }^{23}$. The bait consisted of two kilograms of frozen pilchard Sardinops sagax (Jenyns) that was thawed, chopped and packed into two bait bags made of steel dipped in plastic coating with a square mesh of $10 \mathrm{~mm}$. The field of view was illuminated by eight blue Cree XLamps XP-E LEDs each delivering a radiant flux of $350-425 \mathrm{~mW}$ at wavelengths ranging from 450 to $465 \mathrm{~nm}^{43}$, except for one deployment that used white light. Video analysis and species identification was done on the first 180 minutes of each video deployment. Accurate identification was aided by the collection of voucher specimens of all species, using baited traps deployed at the same locations as the stereo BRUVs. These specimens are registered and preserved in the national fish collection at the Museum of New Zealand Te Papa Tongarewa, Wellington.

1. Forey, P. \& Janvier, P. Agnathans and the origin of jawed vertebrates. Nature 361, 129-134 (1993).

2. Ota, K. G., Kuraku, S. \& Kuratani, S. Hagfish embryology with reference to the evolution of the neural crest. Nature 446, 672-675 (2007).

3. Kuraku, S. \& Kuratani, S. Time scale for cyclostome evolution inferred with a phylogenetic diagnosis of hagfish and lamprey cDNA sequences. Zool. Sci. 23, 1053-1064 (2006).

4. Takezaki, N., Figueroa, F., Zaleska-Rutczynska, Z. \& Klein, J. Molecular phylogeny of early vertebrates: monophyly of the agnathans as revealed by sequences of 35 genes. Mol. Biol. Evol. 20, 287-292 (2003).

5. Martini, F. H. in Biology of Hagfishes (eds J. M. Jorgensen, J. P. Lomholt, R. E. Weber, \& H. Malte) 57-77 (Chapman \& Hall, 1998).

6. Knapp, L. et al. Conservation status of the world's hagfish species and the loss of phylogenetic diversity and ecosystem function. Aquat. Conserv.: Mar. Freshwat. Ecosyst. 21, 401-411 (2011).

7. Smith, C. R. Food for the deep-sea: utilization, dispersal, and flux of nekton falls at the Santa Catalina Basin floor. Deep-Sea Res. Part I 32, 417-442 (1985).

8. Smith, C. R. \& Baco, A. R. Ecology of whale falls at the deep-sea floor. Oceanogr. Mar. Biol. Annu. Rev. 41, 311-354 (2003)

9. Casini, M., Cardinale, M., Hjelm, J. \& Vitale, F. Trends in cpue and related changes in spatial distribution of demersal fish species in the Kattegat and Skagerrak, eastern North Sea, between 1981 and 2003. ICES J. Mar. Sci. 62, 671-682 (2005).

10. Catchpole, T. L., Frid, C. L. J. \& Gray, T. S. Importance of discards from the English Nephrops norvegicus fishery in the North Sea to marine scavengers. Mar. Ecol. Prog. Ser. 313, 215-226 (2006).

11. Davies, S., Griffiths, A. \& Reimchen, T. E. Pacific hagfish, Eptatretus stoutii, spotted ratfish, Hydrolagus colliei, and scavenger activity on tethered carrion in subtidal benthic communities off Western Vancouver Island. Can. Field-Nat. 120, 363-366 (2006).

12. Strahan, R. The behaviour of myxinoids. Acta Zool. 44, 1-30 (1963)

13. Worthington, J. Contribution to our knowledge of the myxinoids. Am. Nat. 39, 625-663 (1905).

14. Auster, P. J. \& Barber, K. Atlantic hagfish exploit prey captured by other taxa. J. Fish Biol. 68, 618-621 (2006).

15. Martini, F., Lesser, M. \& Heiser, J. B. Ecology of the hagfish, Myxine glutinosa L., in the Gulf of Maine: II. Potential impact on benthic communities and commercial fisheries. J. Exp. Mar. Biol. Ecol. 214, 97-106 (1997).

16. Shelton, R. G. J. Of hagfish, goats and sprats. Scott. Fish. Bull. 44, 47-50 (1978).

17. Fernholm, B. in Biology of Hagfishes (eds J. M. Jorgensen, J. P. Lomholt, R. E. Weber, \& H. Malte) 33-44 (Chapman \& Hall, 1998).

18. Fudge, D. S., Levy, N., Chiu, S. \& Gosline, J. M. Composition, morphology and mechanics of hagfish slime. J. Exp. Biol. 208, 4613-4625 (2005).

19. Lim, J., Fudge, D. S., Levy, N. \& Gosline, J. M. Hagfish slime ecomechanics: testing the gill-clogging hypothesis. J. Exp. Biol. 209, 702-710 (2006)

20. Hearle, J. W. S. An alternative model for the structural mechanics of hagfish slime threads. Int. J. Biol. Macromol. 42, 420-428 (2008).
21. Winegard, T. M. \& Fudge, D. S. Deployment of hagfish slime thread skeins requires the transmission of mixing forces via mucin strands. J. Exp. Biol. 213, $1235-1240$ (2010).

22. Fernholm, B. Thread cells from the slime glands of hagfish (Myxinidae). Acta Zool. 62, 137-145 (1981).

23. Harvey, E. S., Goetze, J., McLaren, B., Langlois, T. \& Shortis, M. R. Influence of range, angle of view, image resolution and image compression on underwater stereo-video measurements: high-definition and broadcast-resolution video cameras compared. Mar. Technol. Soc. J. 44, 75-85 (2010).

24. Herr, J. E., Winegard, T. M., O’Donnell, M. J., Yancey, P. H. \& Fudge, D. S Stabilization and swelling of hagfish slime mucin vesicles. J. Exp. Biol. 213, 10921099 (2010).

25. Last, P. R. \& Stevens, J. D. Shark and Rays of Australia. (CSIRO Publishing, 2009).

26. Shelton, R. G. J. On the feeding of the hagfish Myxine glutinosa in the North Sea. J. Mar. Biol. Assoc. U.K. 58, 81-86 (1978).

27. Clark, A. J. \& Summers, A. P. Morphology and kinematics of feeding in hagfish: possible functional advantages of jaws. J. Exp. Biol. 210, 3897-3909 (2007).

28. Subramanian, S., Ross, N. W. \& MacKinnon, S. L. Comparison of the biochemical composition of normal epidermal mucus and extruded slime of hagfish (Myxine glutinosa L.). Fish Shellfish Immunol. 25, 625-632 (2008)

29. Subramanian, S., MacKinnon, S. L. \& Ross, N. W. A comparative study on innate immune parameters in the epidermal mucus of various fish species. Comp. Biochem. Physiol. B 148, 256-263 (2007).

30. Tsutsui, S., Komatsu, Y., Sugiura, T., Araki, K. \& Nakamura, O. A unique epidermal mucus lectin identified from catfish (Silurus asotus): First evidence of intelectin in fish skin slime. J. Biochem. (in press). 10.1093/jb/mvr085.

31. Hashimoto, Y. \& Oshima, Y. Separation of grammistins A, B and C from a soapfish Pogonoperca punctata. Toxicon 10, 279-284 (1972).

32. Bell, R., Carmeli, S. \& Sar, N. Vibrindole A, a metabolite of the marine bacterium, Vibrio parahaemolyticus, isolated from the toxic mucus of the boxfish Ostracion cubicus. J. Nat. Prod. (Lloydia) 57, 1587-1590 (1994).

33. Hahn, M. W., Lunsdorf, H. \& Janke, L. Exopolymer production and microcolony formation by planktonic freshwater bacteria: defence against protistan grazing. Aquat. Microb. Ecol. 35, 297-308 (2004).

34. Pawlik, J. R. Marine invertebrate chemical defenses. Chem. Rev. 93, 1911-1922 (1993).

35. Betz, O. \& Kölsch, G. The role of adhesion in prey capture and predator defence in arthropods. Arth. Struct. \& Dev. 33, 3-30 (2004).

36. Derby, C. D. Escape by inking and secreting: Marine molluscs avoid predators through a rich array of chemicals and mechanisms. Biol. Bull. (Woods Hole) 213, 274-289 (2007).

37. Vandenspiegel, D. \& Jangoux, M. Cuvierian tubules of the holothuroid Holothuria forskali (Echinodermata) - a morphofunctional study. Mar. Biol. 96, 263-275 (1987).

38. Lima, S. L. \& Bednekoff, P. A. Back to the basics of antipredatory vigilance: can nonvigilant animals detest attack? Anim. Behav. 58, 537-543 (1999).

39. Foam, P. E., Harvey, M. C., Mirza, R. S. \& Brown, G. E. Heads up: juvenile convict cichlids switch to threat-sensitive foraging tactics based on chemosensory information. Anim. Behav. 70, 601-607 (2005).

40. Bardack, D. 1st fossil hagfish (Myxinoidea) - a record from the pennsylvanian of Illinois. Science 254, 701-703 (1991).

41. Janvier, P. Early jawless vertebrates and cyclostome origins. Zool. Sci. 25, 10451056 (2008).

42. Eschmeyer, W. N. \& Fong, J. D. Species of Fishes by family/subfamily, $<$ http:// research.calacademy.org/research/ichthyology/catalog/SpeciesByFamily.asp $>$ (2011).

43. Douglas, R. H., Partridge, J. C. \& Marshall, N. J. The eyes of deep-sea fish I: lens pigmentation, tapeta and visual pigments. Prog. Ret. Eye Res. 17, 597-636 (1998).

44. Atkinson, R. J. A. \& Pullin, R. S. V. Observations on the burrows and burrowing behaviour of the red band-fish. Cepola rubescens L. PSZNI Mar. Ecol. 17, 23-40 (1996).

\section{Acknowledgements}

The MV Tranquil Image crew N. Furley, G. Gibbs and S. Kelly helped to organize all of the fieldwork using baited underwater video units. R. Crech'riou, A. Smith, C. Bedford, O. Hannaford and K. Rodgers contributed to the sampling effort. This work was supported by a Royal Society of New Zealand Marsden grant (MAU0713), Te Papa Collection Development Programme (AP3126) and FRST/NIWA Marine Biodiversity and Biosecurity OBI (contract COIX0502). Scientific illustrator M. Freeborn drew Figure 3.

\section{Author contributions}

V.Z. and C.D.S performed sample collection with the essential technical support of E.S.H. and financial backing from C.D.R. and M.J.A. The video footage was reviewed and analyzed by V.Z., who also organized and prepared the figures and supplementary videos. The initial draft of this manuscript was written by V.Z., C.D.R., and M.J.A and relied heavily on essential preparatory material and text written by V.Z., C.D.R., C.D.S. and A.L.S. All of the authors discussed the results and contributed to the writing of the final draft of the manuscript. 


\section{Additional information}

Supplementary information accompanies this paper at http://www.nature.com/ scientificreports.

Competing financial interest: the authors declare no competing financial interests. License: This work is licensed under a Creative Commons
Attribution-NonCommercial-NoDerivative Works 3.0 Unported License. To view a copy of this license, visit http://creativecommons.org/licenses/by-nc-nd/3.0/

How to cite this article: Zintzen, V. et al. Hagfish predatory behaviour and slime defence mechanism. Sci. Rep. 1, 131; DOI:10.1038/srep00131 (2011). 